\title{
Practical Vitality of Green Bonds and Economic Benefits
}

\author{
Ankita Kant
}

Durham University Business School

e-mail: ankitakant.1125@gmail.com

\begin{abstract}
Climate change is an overarching challenge for achieving sustainable development. "Green" or "Climate" Bonds are often seen as a financial instrument that may help overcome low-carbon investment defiance. This paper explores green bonds' potential contribution to low-carbon transition and the corporate sector's benefit following the stock market reaction. This paper focuses on a new and fascinating subject because the green bonds market is under constant scrutiny since the emergence of the first green bond in 2007. Anticipating the significance of action towards climate change is continuously increasing over time. This project can be seen as a supporting argument for investing in green bonds and fighting against climate change. This study investigates the recent developments and challenges in the green bond market. I used matching criteria and performed multivariate OLS regression to test whether the green bond is priced differently than conventional ones. The result finds that green bonds are cheaper than conventional bonds with a 1.93-2.24 per cent premium, consistent with prior studies in this topic. I used a sample of 200 corporate green bonds issued after the Paris Agreement, i.e., from December 2015 to December 2019. I further document that the stock market reacts positively to green bonds' announcements. For this, I performed the CAR test on a company's stock price, which gives a statistically significant abnormal return of 0.23 per cent and 1.14 per cent over time windows 10 and 20 days, respectively. Moreover, green bonds' environmental performance on carbon emission reduction proved to be an insignificant player. For this, I tested a relationship between green bond labels and the firms' carbon emission. The mixed results suggest that maybe green bonds are performing well economically, but it is still far from achieving its practical goal.

Keywords: green bonds; corporate social responsibility; corporate finance; carbon emissions

JEL Classification: G12, G14, G32, M14, Q52, Q53
\end{abstract}

(c) Ankita Kant, 2021

\section{Introduction}

The concern over the acceleration of climate change is real. Ever since the tracking of climate change began in 1880, the six warmest years on record for the planet have all occurred since 2010 (National Oceanic and Atmospheric Administration NOAA, 2018). The rising temperature and increasing acidity of ocean water, melting of ice sheets, and glaciers which result in climbing sea levels and the growing frequency of droughts and floods reflect the threat to the planet by increasing atmospheric carbon levels (Baker et al., 2018). There is an urgent need to tackle this problem which comes with the cost of enormous sums of money that adapt to existing conditions or foreseeable changes. Climate has become the most significant theme in ESG (Environmental, Social and Governance) investing and there is an acceleration of product development in the past couple of years, triggered by the Paris Climate Accord in 2015 and the need to keep global warming to below two degree Celsius (Financial Times, 2019). So, what exactly counts as a climate-friendly investment strategy? The hottest and efficient way of tackling the problem is green bonds, a way for issuers to raise money specifically for environmentally friendly projects such as renewable energy or clean transport (Bloomberg, 2019). Large sums of capital are needed to finance responses to and preparations for climate changes. In order to connect the money to the solution, green bonds 
are the tool that may be used to reach investors and collaboratively finance low-carbon, and climate-resilient solution. Green Bonds have attracted countries, supranational institutions, corporations, and investors to invest in green investment. For example, Unilever issued a $£ 250 \mathrm{M}$ green bond supporting "cutting half the amount of waste, water usage, and greenhouse gas emissions of existing factories" in March 2014 (Financial Times, 2014). Similarly, in June 2017, Apple issued a \$ $1 \mathrm{bn}$ green bond to finance "renewable energy and energy efficiency at its facilities and in its supply chain" (Forbes, 2017). Henceforth, this study provides an insight into the practical role of the green bonds as raising funds for green projects.

The green bond market emerged in 2007 with a triple-A-rated issuance from multilateral institutions European Investment Bank (EIB) and the World Bank. The green market's broadness acted after a positive reaction of the first USD $1 \mathrm{bn}$ green bond sold within an hour of an issue by IFC in March 2013. The following year was the market's turning point as the first corporate green bond issued by Vasakronan, a Swedish property company. Large corporate issuer includes SNCF, Berlin Hyp, Apple, Engie, ICBC, and Credit Agricole. The momentum has continued, with over USD 500bn in green bonds currently outstanding (Climate Bond Initiative). The majority of Green Bonds issued are Green "use of proceeds" or asset-linked bonds. There have also been "Use of Proceeds" Revenue Bond or ABS, Green Project Bonds, Securitisation bonds, Covered Bonds, Loan, and Other debt instruments. Proceeds from these bonds are earmarked for green projects, refinancing green projects, and portfolios of green projects, and ring-fencing the specific underlying green projects.

This study examines the green bond market compared to its counterparts and whether they provide a premium to investors and whether it is impacting the reduction of greenhouse gases such as $\mathrm{CO}_{2}$. This thesis covers the green bond market of a specific period, that is, after the Paris Agreement of December 2015 to December 2019, four years. This study will focus primarily on non-financial companies where traditional valuations are more applicable. In general, a company's fundamental value can be calculated by discounting its future cash-flows into a present value with a certain discount rate. Here, the only focus will be the divider of that equation, discount rate, or coupon rate. If green bonds proved to be cheaper than conventional bonds, the company's future cash flows are then discounted with a lower rate into a present value, increasing their current value.

To empirically examine the corporate green bonds, I compile a dataset of corporate green bonds from Thomson Reuters Eikon green bond tag. The empirical analysis documented several stylised facts pertaining to corporate green bonds. First, as mentioned above, corporate green bonds have become increasingly popular over time. Second, corporate green bonds are more prevalent in industries where the natural environment is financially material to the companies' operations (e.g., energy). The corporate green bonds are especially pervasive in China, the US, and Europe.

Further, I examined how the stock market responds to green bonds' issuance using an event study methodology. The result indicated that the stock market responds positively in a short time window, which is in line with many previous pieces of literature such as Flammer (2020); Tang and Zhang (2018).

Focusing on the environmental perspective, the orientation of investments to sustainable activities has also been possible because of the Green Bonds. The difference with conventional bonds lies in the issuer's commitments on using the proceeds, which must have positive externalities for the environment. In this study, I carried out a regression of green bond issuers' environmental performance by taking carbon emissions as a dependent variable. The experiment shows no statistically significant relationship between them. One explanation could be the recent emergence of the green bonds market, which is still much far away from the goal to mitigate carbon emission.

Additionally, this study's factual explanation is the companies' greenhouse emission data's lack of details. Following Flammer (2020) methodology, who uses Thomson Reuters ASSET4 for getting environmental rating data, found no mechanical link between the issuance of green bonds and higher environment ratings. To mitigate this issue, they used the ratio of $\mathrm{CO}_{2}$ emissions divided by the book value of assets as the emissions are more objectively measured. This metric interpreted more sensible results that blend several corporate environmental behaviour dimensions. 


\section{Purpose, Motivation, and Limitations of the Study}

This study's main purpose is to check the overall performance of the green bond within a company and its impact on the fight against climate change. Firstly, the financial benefits of green bonds are checked by finding whether they are priced lower than ordinary bonds which attract the investors to invest more in climate-friendly projects. Thus, whether green bonds can be proved to be issued with significantly cheaper yield, it should also mean that if a company is using a green bond to fund its operations and investments, the discount rate is lower as resulting in a higher present value of the companies' future cash flows. Secondly, this thesis examines the company's stock price reaction on green bonds' issuance. This study also examines green bonds' environmental performance by checking the relation between the green bond environmental rating and carbon emissions changes.

The impact of climate change poses a significant threat to this planet. There is an urgent need to finance mitigation and adaptation efforts at various levels to combat climate change successfully. Green Bonds are relatively new funding instruments for green projects that have steadily become the first line of defence against climate change. If the green bonds are more attractive with a lower yield than conventional ones, investors consider when making new investments and project strategies. The basic responsibility for good sustainability with issuers and within the organisation internally provides a rational insight into what they are going to invest. It is the primary motivation of this study.

This study's limitations could be the lack of data available and manipulation in the matching of green bond and conventional bond data compared to the prior studies of this subject. It can have some effect on its result. Green bonds and green investment markets are new. Despite in-depth research on the necessity and impacts of green finance and Green Bonds, there is little empirical evidence of these investments' financial performance. But the concern for climate change is growing worldwide, and the demand for green bonds is increasing rapidly. Various studies are on-going, and several prior tests have occurred in recent years and therefore support this the- sis, though not very strongly. Another limitation worth mentioning is that this study uses only one valuation method and should not be taken as absolute truth but more as an indicative result.

\section{Green Bonds}

Green Bonds are a new asset class issued to raise finance for climate change solutions. This chapter will cover some basic principles of green bonds and their operation. It will also cover one real-life example of green bond issuance and expectations and threats to the market and issuers. Increasingly, investors see both the financial and social imperative for sustainable investing, particularly green bonds' rapid growth.

These figures illustrate the growth in the green bond market over a decade and shows which kind of companies are most active in issuing green bonds. The number is promising, and the bonds' amount of investment is tremendous. In the second figure, we can see that the non-financial sector covers almost 40 per cent of the total green bond issuance which is a notable change as supranational institutions like the European Investment Bank and World Bank were dominant at the beginning of the green bond markets. In 2018, the top market trend for green bonds was the rise of a broader range of socially conscious debt levels. The return of volatility to financial markets negatively impacted overall bond sales and the taxonomies were revised, for example, Loan Market Association (LMA) published the Green Loan Principles (GLP), with the support of ICMA and Climate Bond Taxonomy was updated with new sectors and more exact definitions (Climate Bond Initiative).

\section{Definition and Principles}

Green Bonds are a financial debt instrument widely used to fund more energy-efficient technologies, reduce carbon emissions, and further sustainable economic activities. They are mostly issued by the government, corporations, and financial institutions. Investors who want to recast their investments to address climate change will face several decisions over what companies or funds to invest in and how to reduce the risks associated with their portfolio, and what returns they might be sacrificing or gaining by transforming portfolio. Green Bonds create a marketplace that potentially increases the transparency 


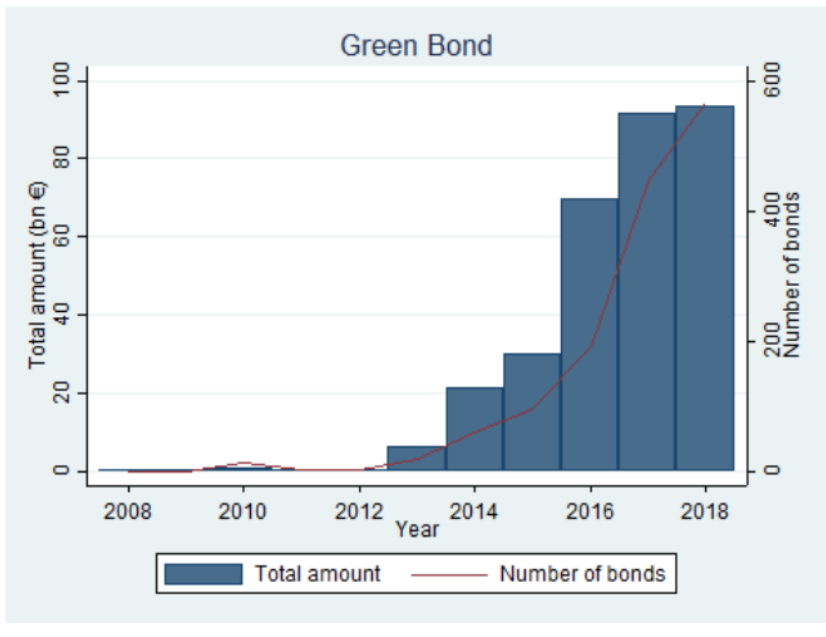

Fig. 1. The Green Bond Market

Note. The figure reports the total amount of Green Bond issued (bars) yearly (billion euros). The line shows the total number of green bonds issued from 2008 to 2018.

Source: Fatica, Panzica, \& Rancan, 2019.

of the information about the underlying asset and the companies using it.

Various papers conclude the set of use of proceeds which describes the subjects of the projects financed by the proceeds. International Capital Markets Association (ICMA) has defined green bond as a "the type of bond instrument where the proceeds will be exclusively applied to finance or refinance, in part or as a whole, new and/or existing eligible Green Projects" (ICMA, 2018). The project categories according to ICMA guidelines for issuing a Green Bonds:

Renewable Energy

Pollution prevention and control

Energy Efficiency

Environmentally sustainable management of living natural resources and land use

Terrestrial and aquatic biodiversity conservation

Clean transportation

Sustainable water and wastewater management

Climate change adaptation

Eco-efficient and/or circular economy adapted products, production technologies and processes

Green Buildings

(Source: ICMA, 2018)

According to the guidelines, the green bond market aims to create an opportunity and marketbased solution that debt markets, investors and companies could use in funding projects. The next table will present the green bond market's value from 2015 to 2019.

\section{Sector Breakdown}

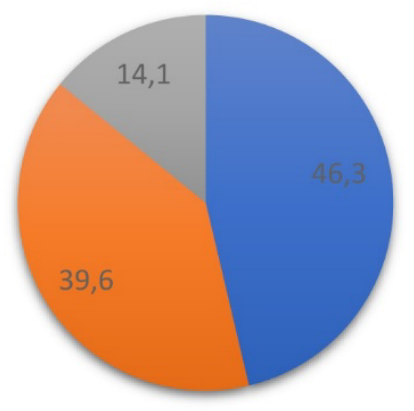

- Financial 46,3

non Financial 39,6

- Supranational 14,1

Fig. 2. Green Bond Market Distribution by issuer type in percentage

Source: Chart taken from Fatica, Panzica, \& Rancan (2019).

As we can see from the above table, the growth in Green Bonds' revenue has increased over four years, which means both investors' interest and the bonds' performance significantly improve over the years. The alternative energy sector has the highest issuance of approximately 21 per cent revenue. Other sectors are also in increasing trend.

The proceeds of the green bonds should be managed and tracked appropriately through a formal process that should also be transparent to build a positive profile in the market., It is recommended the use of external auditors to enhance transparency. It is also important that the issuer clearly presents the environmental benefits of the green projects and if possible, quantified as well so that independent evaluators can verify them. An external review is very important to increase transparency and develop trust in the green bond market. It is particularly important in the case that the issuer does not have much expertise to provide the required information, or in some cases where project generate negative environmental impact (Sartzetakis, 2020). There are several types of reviews for the same, such as consultant review, verification, certification, and rating (ICMA, 2017). Thus, if the issuers label the green bond, the market could become more substantial.

\section{Green Bond market in $\mathbf{2 0 2 0}$}

Due to the sharp increase in Climate activism and fear of an apocalypse, green investments 
The top sectors for Green Bonds issuance in 2015 and 2019

\begin{tabular}{ccc}
\hline Category & 2015 & 2019 \\
\hline Alternative Energy & $\$ 30.4 \mathrm{~B}$ & $\$ 143.8 \mathrm{~B}$ \\
Green Building & $\$ 10.7 \mathrm{~B}$ & $\$ 63.5 \mathrm{~B}$ \\
Sustainable transport & $\$ 3.7 \mathrm{~B}$ & $\$ 58.7 \mathrm{~B}$ \\
Energy Efficiency & $\$ 9.5 \mathrm{~B}$ & $\$ 47.6 \mathrm{~B}$ \\
Sustainable water & $\$ 3.1 \mathrm{~B}$ & $\$ 23.8 \mathrm{~B}$ \\
Pollution prevention & $\$ 1.4 \mathrm{~B}$ & $\$ 18.1 \mathrm{~B}$ \\
Climate Adaption & $\$ 1.8 \mathrm{~B}$ & $\$ 15.0 \mathrm{~B}$ \\
Sustainable forestry/agriculture & $\$ 1.1 \mathrm{~B}$ & $\$ 11.3 \mathrm{~B}$ \\
\hline
\end{tabular}

Source: $\mathrm{MSCl}$

have been rising in popularity (The Trumpet, 2020). The recent COVID-19 pandemic has given more momentum to green bonds around the globe. With its attractive attributes of tax exemption for investors, the market for green bonds has rapidly grown over the years. In 2019, green bonds were issued worldwide for $\$ 205$ billion, more than 20 times as much as 2014 (\$9 billion). According to the Climate Bond Initiative (CBI), the European Union is the largest international green bond market. The CBI forecast 2020s says the global annual green bond and loan issuance to be $\$ 350$ billion to $\$ 400$ billion, and $\$ 1$ trillion in annual investment by 2021/22.

\section{The Coronavirus Effect}

By the end of April 2020, more than $\$ 50$ billion worth of green bonds were issued (Climate Bond Initiative), which was lower than the market's anticipation. The financial market is highly disrupted worldwide, but green bonds, or debt earmarked for specific environmental projects, have held up better than the broader investment-grade corporate market. It is due to less weighted toward cyclical sectors, such as oil and gas (The Trumpet, 2020). However, I think this pandemic could work as a catalyst to convince the wider community and transform it into a lifetime opportunity to invest in climate-friendly future and economic sustainability.

\section{Green Bond Pricing}

Green Bond costs almost the same as Conventional Bonds (Tang \& Zhang, 2018). Kapraun and Scheins (2019) analysed the pricing of a sample of over 1,500 Green Bonds on Primary and Secondary market. They found only certain types of Green Bonds issued by the government or supranational entities or corporate bonds with huge issue size exhibit lower yield, i.e., trade at a premium relative to their conventional counterparts. Further study by Fatica, Panzica and Rancan (2019) compared the pricing implication of Green and Ordinary bonds and examined which determinants of the bonds affect the yield by carrying out the regression model. The study found that there is not always a premium in green bond issuance price unless supranational or corporate is behind the issuance, the premium is found. Their research also suggested that the green bond's repeat issuance has some price difference compared to the conventional ones, and second-time issuance provides some premium on the yield.

Besides, Karpf and Mandel (2017) investigate the yield term structure of green and brown bonds from the US municipal bond markets. They asserted that, although the returns of brown or ordinary bonds are higher than green bonds on average, this spread can be explained by the bond issuing company's profile and determinants. In general, a flattening slope on the yield curve reflects lower returns from the bonds. According to Karpf and Mandel (2017), flattening yield curve is more present in green bonds than brown ones, which undoubtedly favours brown bonds in an investor's eye, but it is cheaper for them to get from issuers angle issue green bonds.

The following picture shows how differently green and conventional bonds are priced in the market. 
Their study further concludes that there is a positive and statistically significant spread between ordinary and green bonds on average, which aligns with Fatica, Panzica and Rancan (2019).

In this thesis, the regression on the yield differentials between green and normal bonds explores the significant positive impression with coupon and the other determinants. It ultimately proves the efficiency of green bonds over ordinary bonds.

\section{Practical Vitality of Green Bonds in Investment}

This subchapter focuses on Green investment's green bond market's practical usage. A real-life case study is taken from the Climate Bond Initiative case study library, including the summary of bond issuers' experience and challenges.

\section{Water Green Bond: A Case Study}

An old infrastructure in Washington DC created risk from severe and frequent storms. The dumping of billion gallons of raw sewage into its river annually, made the area inhabitable. The plan for adaption and mitigation was to build a tunnel to retain water from combined sewer overflow. For that, they decided to fund the part of the project by 100 years, Green Bond. They were first considering issuing a normal bond but looking at the asset's characteristics, and potential positive environmental outcome. A $\$ 350 \mathrm{~m}$ bond was planned, upsizing from the $\$ 300 \mathrm{~m}$ issuance due to the strong demand. According to them, when the project completes in 2030, it will reduce combined sewer overflow to the Anacostia River by 98 per cent.

The project required a long planning and reviewing phase. From conception to execution the deal was lengthy and complicated than a traditional bond issue process. The project leader developed a relationship with investors, investment bankers (Barclays and Goldman Sachs), and a Second Opinion Provider (Viego). (Irene, 2016) Assessment and modelling of the initiative were carefully developed and implemented. DC Water was already a bond issuer, and Clean Water Project was a big project. It would fit the Green Principles and the World Bank model as a green project with environmental benefits.

The Green Bond model adds layers of complexity and increases integration systems. It adds components to the system: transparency of what is

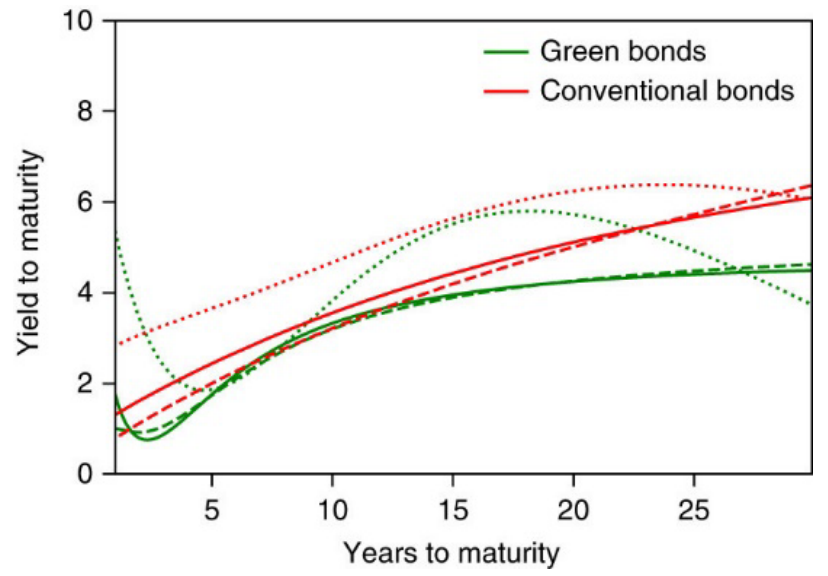

Fig. 3. The yield term structure of Green and Conventional Bonds

Note. Yield curves, representing the relation between the yield(y-axis) and the time to maturity (x-axis). The solid line is overall performance, a hashed line is A-rated bonds, and the dotted line is $B$ rated bonds.

Source: Graph is taken from Karpf and Mandel (2017) study.

being financed, tracking of cash flows, and reporting the investment impact. The system designed by this company for 100 years term has multiple intentional benefits which include investors numbers and an increase in equity.

We can say Green Bonds provide an opportunity for multiple stakeholders to collaborate. It offers an arena for innovation as new kind of bonds, such as DC Water 100 years bond, are creatively designed. Green Bonds have mobilised development of methodologies to measure and report the impact of environmental solutions. Green Bonds can make green projects less expensive, i.e., high demand for the bond can create a lower interest rate for the issuer (borrower). It can result in cost optimisation of capitals for the organisation that is issuing the Green Bond (as we have seen DC Water reduced its interest rate in response to high demand). It solves the problem of water quality and improves the quality of life and offers economic opportunities in the disadvantaged area of Anacostia River. A bond is issued on many factors, one of which is the length of asset which it finances. In this case, a combined sewer overflow system was expected to last more than 100 years, so the concept of a hundred-year bond was creatively implemented.

Overall, this case study is a perfect example of explaining how green bonds can be used to finance a various project in a cost-efficient way. 


\section{Market Mechanism and Risks}

With the increasing attention on the green bonds and climate bonds over the past few years as key instruments to finance the transition towards a low-carbon economy, they shall remain small compared to the challenges it is meant to address and the overall traditional bond market. Therefore, it is essential to understand the mechanisms and risks involved in the market. These instruments' positive aspects have been discussed, which is the primary motivation of this study. However, understanding the risk is one of the crucial parts of any project to carry on. According to the studies, there are three major risks involved in the issuance of the green bond and market. Firstly, a lack of liquidity risk is one of the largest detractors. It impacts the issuers and investors as in the current investing environment, the green bonds' investors might need to hold until maturity. Chandrasekaran (2018) examines how liquidity affects the green bond yield spreads and found a significant impact on the green bond yield spreads and urged issuers to improve their liquidity levels to reduce the risks and increase confidence among investors. Furthermore, Febi et al. (2018) analysed the yield spreads between corporate and government bonds using controlled variables by pooled OLS model and found that green bonds are more liquid during 2014 to 2016 than conventional ones. Additionally, their results also suggested that the green bond spread's liquidity risk is becoming insignificant over time and can be associated with the markets' growing maturity.

Another risk for green bonds includes low yields, mispricing, and insufficient complex research, leading to wrong investment decisions. Also, lack of a clear definition for a green bond is a risk-investors might be not knowing where they are putting their money, meaning it could potentially be used for the wrong reasons.

\section{Greenwashing}

Although the market for green bonds is in rapid development and significantly shows positive impacts on the companies and environment, corporations are more engaged in socially responsible ways of doing business. Still, there are always some who unethically take advantage without actually involving in real action. Situations where company launder monetary bene- fits from the environmental-friendly operations creates possibilities of dishonest actions. Hence, this risk of Greenwashing can bring uncertainty and disbelief in the market, whereas they are intended to bring an effective solution and change in the world. In general, greenwashing can be described as a form of marketing and advertising company's ethical and environmental values with a purpose to attract investors and consumers rather than actually implementing environmentally friendly practices. For example, British Petroleum shifted its slogan to green in 1997 when acknowledged a link between global warming and fossil fuel. They hired an advertising firm to launch a $\$ 200 \mathrm{~m}$ rebranding campaign and rebranded to Beyond Petroleum. They greenwashed itself by working with green groups and decorating its gas station with green images. Despite British Petroleum's attempt to greenwash, the company is a fossil fuel company that derives its revenues from polluting air and destroying the planet (CFI).

Few prior studies have presented this rationale; for example, Laufer (2003) and Beder (1997) presented problems and challenges of ensuring fair and accurate corporate social reporting. They gave a couple of rationale on companies practising greenwashing and how these actions can be categorised into confusion, fronting, and posturing. According to their studies, greenwashing is pervasive since the introduction and might significantly impact the green bond market. And suppose the green bonds are priced cheaper than the ordinary bonds and claims more investors only by their tag, and other hypotheses of the study hold. In that case, it might be a motivation for the opportunist to practice greenwashing.

\section{A Review of Green Bond as an Instrument to Finance Low Carbon Emissions}

One of the most important roles of Green Bond that an investor is anticipating is to finance the economy with low carbon value to mitigate climate change, for that most of the countries are using a combination of Carbon Pricing and Green Bonds.

In the Paris Agreement, countries worldwide made a commitment to transitioning towards low-carbon, climate-resilient economies. Several policy instruments have been proposed to finance this transition, including green bonds and car- 


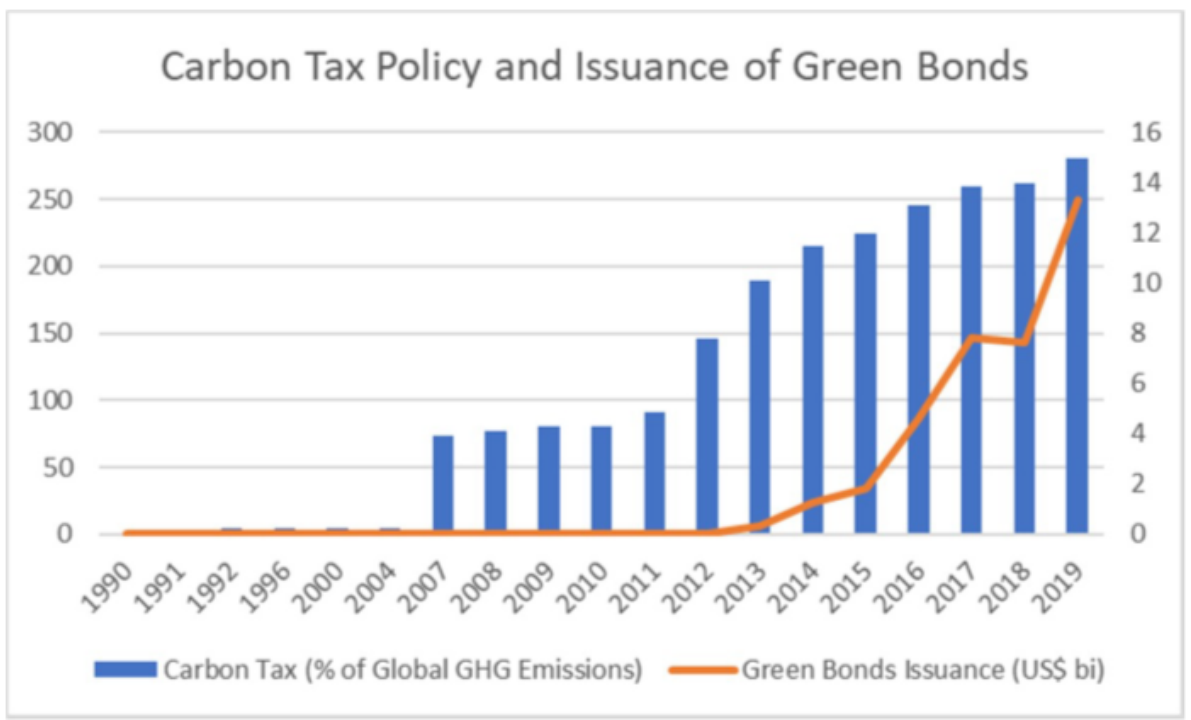

Fig. 4. The increment in carbon pricing since 1990

Source: Climate Bond Initiative (2019) and World Bank (2019).

bon pricing. This instrument still has to prove its credibility, but researches have been carried out to find the important gains from deploying them jointly. Debt levels are rising in many low-income countries (Essl et al., 2019). In such circumstances, climate policy should be financed by taxation or budget reallocation instead of deficit spending (Forni et al., 2019). Heine et al. (2019) observed that Carbon Pricing improves the performance of green bonds, which in turn improve inter-generational equity, political feasibility, and help address multiple market failures with speeding up the transitions.

In the form of carbon taxes or emissions trading schemes, carbon pricing has been used since the 1990s as a stimulus for diminishing greenhouse gas emissions, and since then spread to 46 jurisdictions, rising by up to 43 billion in revenues (Heine et al., 2019). Green Bonds portray a more modern development in the policy toolkit for financing climate change mitigation, adaption, or conservation of natural capital resources. Despite their exponential uptake since 2011-12, the carbon emission coverage is less than 5 per cent under explicit carbon pricing initiatives which says both instruments are still too small for containing climate change.

The main purpose of carbon pricing is to make consumers and producers of polluting goods more considerate of the costs imposed by this pollution in the environment. The pricing policies, such as carbon taxes or emissions trading systems (ETS), mixed with green bonds, will achieve greater envi- ronmental effectiveness and lower overall mitigation costs. In principle, the needed for financing for a low-carbon transition could be met entirely from pricing externalities. The IMF estimates that the gap between the present taxation of fossil fuels and the level of taxation justified by external costs amounts is more than estimated financing needs to contain global warming (Blanchard, 2019). Despite its potential, the present carbon pricing level is entirely insufficient to meet mitigation needs. "Few countries are taking some modest steps forward, yet there is little evidence of better use of taxes on energy which is a mounting environment and climate challenges globally. Instead, real tax rates are gradually eroded by inflation in most countries, suggesting indifference to the environmental efficacy of taxes" (OECD, 2018). Unless a breakthrough in fiscal policy can be achieved, additional financing sources of mitigation, such as green bonds, are indispensable. Therefore, the Finance Ministers and Central Bank Governors that embrace carbon pricing equally call for stepping up green finance instruments (Climate Bond Initiative, 2016). The green technology revolution will require investment across the innovation chain, similar to that observed in the information and communication technology revolution (Mazzucato, 2015; Norberg-Bohm, 2000). Public investments should play a vital role in this change to actively create low-carbon climate-resilient markets (Mazzucato, 2016; Hallegatte et al., 2013).

From 2010 to 2018, the European Union (33.4 per cent), China (14 per cent), Multilateral Or- 
ganisations (13.7 per cent), and the United States (12 per cent, excluding US municipalities bonds) were the world largest Green Bond's issuers (Heine et al., 2019).

Heine et al. (2019) reviewed the efficiency benefits from including such carbon pricing in a joint policy with green bonds. They analysed the interaction effects which arise when green bonds and carbon pricing are implemented jointly, where there are two options available for implementing carbon pricing: ETS and taxes. According to them, the interaction effect between the value of green bonds and carbon prices is more ambiguous for ETS than for carbon taxes. An ETS puts a cap on emissions, and emissions leakage can occur when green bonds finance climate change mitigation projects for industries covered by the cap, thereby allowing the displacement of emissions rather than their net reduction. To prevent this, green bonds should be introduced to tighten the cap, but those adjustments may be politically impossible precisely when green bonds are sought. However, Green Bond holders have an interest in tightening the ETS caps. The industries' lobbying to loosen emissions caps could be counterbalanced by new lobbying from these investors. By that means, the creation of green bonds could both strengthen or weaken ETS. As the tax is more stable irrespective of green bonds' deployment, the risk that green bonds and carbon taxes will cripple each other diminishes. Another interaction effect between green bonds and carbon prices works through price volatility (Heine et al., 2019). Compared to other bonds, green investment projects can attract green bond financing more easily if returns on investment are less volatile (Gevorkyan et al., 2017).

In this thesis, the effect of the green bond's issuance on carbon emissions has been shown. The fact above concludes that an increase in carbon tax puts a significant cap on emissions and thus reduces carbon emission on firm-level. That also means if the carbon tax is low, green finance may improve welfare. I will further discuss the Green Bond tag's potential benefits on the carbon emission.

\section{Literature Review}

This paper revolves around finance and the environment and thus relates to different strands of financial literature. Because the concept of green bonds is relatively new and still under development, it will follow with the latest published literature and working empirical papers along with the older studies. Therefore, I based literature review only on the important findings rather than a comprehensive overview of all the previous research on the subject. This line of the thesis is divided into two parts. Thus, the empirical evidence review will be carried out in two sections: research about the pricing of the green bonds and its on-going effect on carbon emission reduction. The literature review of related studies gives a better picture of the area and supports my study's problem.

\section{Pricing of Green Bonds}

Most research carried out in this line of the topic is the pricing of the green bonds compared to the conventional bonds. Fatica et al. (2019) found that the green bond issued by supranational and corporations are priced at a premium while there is no effect for financial institutions. Kapraun and Scheins (2019) studied bond pricing's green credibility in the primary and secondary market. They found 18 bps lower yield at the issuance of green bond issued by the government or supranational entities, denominated mainly in EUR and USD, or corporate bond with very large issue size. They also argued that investors are more likely to consider a corporate bond as Green when the bond is certified by a third party, or when the bond is listed in exchange with a dedicated green bond segment. According to the Climate Bond Initiative, Assurance is an important part of the Climate Bonds standard and certification scheme. It is highly valued by investors and other stakeholders in the green bond market.

In contrast, Karpf and Mandel (2017), Hachenberg and Schiereck (2018), Larcker and Watts (2019) document no significant difference in yields or even higher yield for green bonds. However, most of these studies rely on a minimal set of bonds or focus on special types of bonds (e.g., US municipals) or markets (primary or secondary). Gianfrate and Peri (2019) stated that there is a statistically significant proof when an issued bond is labelled as green, these benefits will exceed costs. Their results observed the yield premium around 18 basis points, which equals 0.18 per cent of the overall bond value. Their study took the additional costs of issuing the green bonds, 
certifying, monitoring, reporting cost about the green use of proceeds, and the monetary benefits for the issuers who exceed these costs. For example, the Climate Bond initiative takes a 0.1 basis points fee for each to certify the green label. It means that if the amount of green bond issuance is 1,000,000 EUR, these costs will be 1,000 EUR. Third party involvement for assurance also increases the costs.

Ehlers and Packer (2017), Baker et al. (2018) found the premium on average relative to conventional bonds if the currency risks are hedged. The former also documented that green bonds are exposed to a relatively high degree of environmentally-related financial risks. Contrary to their findings, Zerbib (2018) found that the yields of green bonds issued between 2013 and 2017 are on average, two basis points (bps) lower than those of comparable conventional bonds. But the negative premia are more pronounced for financial and low-rated bonds. One common explanation for this yield difference is the high demand and limited supply of green bonds.

These previous findings show that even after all the surplus costs associated with Green Bonds issuance, these debt instruments are still a relatively cheaper and efficient form of financing for the issuers. As a result, green bonds effectively improve the concern of climate change by funding and significantly benefit the issuers in terms of the reduced cost of debt. With this argument of Green bonds being more of a charity investment than a financially interesting instrument, the financing through these instruments against climate change should get more further attention and support.

\section{Market Reaction}

So far, the findings suggest that green bonds are priced cheaper than ordinary bonds. It is also essential to find the relation between the green bonds' issuance and those bonds' stock price. Few research studies have been carried out following this topic, for example, using an event study model to determine how investors and shareholders respond to corporate green bond issuance. Tang and Zhang (2018) documented positive stock price reaction to the green bond issuance, but they did not find any premium suggesting that the lower cost of debt does not drive the positive stock market returns.
Their study also presented the finding that the proportion of shares owned by domestic institutions tends to increase after the green bond issuance. This finding is also very indicative for this study as it will guide the methodology of this thesis and provide a comprehensive insight for data analysis.

Glavas (2018) found that the stock price reaction grew after the Paris Agreement, which supported the change of equity investors' behaviour after this agreement. They carried a rigorous event-study at each announcement date with regression analysis. This paper is also a very important reflection for this thesis as the data selection period is after the Paris Agreement.

Flammer (2018) used only an event-study as a complementary analysis to test the market response to green bond issuance. However, according to Glavas (2018), there are no tests implemented yet to determine whether the debt component or the "green" component of the green bonds is responsible for this positive market reaction.

On the other hand, Lebelle et al. (2020) used an international sample of corporate Green Bond and used CAPM, the 3-factor Fama and French models and 4-factor Cahart models; they found that the market reacts negatively to the announcement of green bond issuances. They also supported their argument with the first green bond issuance theory and suggested that green debt offerings convey unfavourable information about the issuing firms.

Several event studies document positive abnormal returns in response to the companies' ecofriendly behaviour (e.g., Flammer 2013; Klassen, \& McLaughlin, 1996; Krueger, 2015). These findings suggest that bond issuance announcements have a mixed reaction from institutional investors.

\section{Environmental Performance}

The orientation of investments to sustainable activities through Green Bonds from the environmental perspective has been studied only in a few cases. For example, Flammer (2020) studied the green bonds' environmental performance post-issuance and found that the issuers indicated higher environment ratings and lower $\mathrm{CO}_{2}$ emissions. Their finding also suggested that as the companies' environmental performance improves and becomes more attractive for an investor's clientele, it is sensitive to the natu- 
ral environment. They found a positive link between companies' environmental responsibility and stock market performance.

Heine et al. (2019) used the combination of carbon pricing and green bonds in a three-phase model and used the numerical solution procedure. They modelled the interaction using an intertemporal model that proposes the burden-sharing between current and future generations. Their results showed that green bonds performed better when they are combined with carbon pricing. Sartzetakis (2020) also examined central banks' role in financing the low carbon economy and theoretically argued the intergenerational burdensharing and long-term infrastructure investments. While most of the literature researched the practical usage of green bonds through the intergenerational burden-sharing method to mitigate future environmental damage, this paper checks if there is a reduction in the carbon emission after the green bond market has taken place, i.e., Paris Agreement. Flammer (2020) is the main motivation to carry out this study.

A recent report on BBVA green bonds mentioned that the project financed with green bonds in 2018 and 2019 avoided a total of 724,000 tons of $\mathrm{CO}_{2}$ atmospheric emissions, which is almost three times than the previous year. It shows that funding the environment projects through green bonds' issuance helps achieve Sustainable Development Goals (SDG).

\section{Data}

This paper focuses on the practical side of Green Bonds. It examines whether the Green Bonds are priced differently from conventional bonds and how Green Bonds' issuance has impacted the issuers. In the second part, whether the low carbon economy is built with the Green Bond tag and carbon emission reduction is discussed. This section describes the data collection method and the synopsis of methodologies used in this paper. As mentioned above, Green bond market is new and continuously developing; there is a mere risk of adequacy and quality in the information extraction. I used three basic econometric methods to check a structured hypothesis and formulate my conclusions. Firstly, an OLS regression intends to give a result on the statistical difference in green and conventional bonds' pricing. Secondly, an event-study analysis exam- ines whether green bond issuance impacts the company's stock price. Cumulative Abnormal Return (CAR) analysis is checked using Microsoft Excel mathematical formulas for this method. The third part of this study again uses OLS regression which checks upon the green bond tag and carbon emission statistical relevance. $R$ software is used as a modelling tool mainly to implement regression and descriptive data tables. The data is cross-sectional so a simple OLS regression with some robustness test can give some reliable results.

The main source of data used in this thesis is Thomson Reuters Eikon, which covers primary and detailed data about the corporate bond issuance and other market parameters. This study selected all the corporate bonds issued by non-financial companies after the Paris Agreement, December 2015 to December 2019. I separated the bonds on the qualitative information on the bonds' features, such as the nature of the projects for which the proceeds are used, the issuers' sectors, and the grade. This study selected corporate bonds on their characteristics of the instruments, whether they are green or conventional bonds. For example, government and supranational bonds are excluded in terms of lacking their valuation needs. Data shows that most of the Green Bond issuance has been made by the corporate sector, with financial institutions having the highest cumulative amount so far. It is partially explained by the strong reliance of financial firms on the bond market (Fatica, Panzica, \& Rancan, 2019). However, this sample has not included the financial institutions' bond because of these issuers' specificities regarding leverage and regulation. Further, I used all available bond characteristics (such as Coupon, maturity, Duration, Callable, Puttable, Convertible) as a controlled variable in an attempt to limit disparity on bond characteristics between green and conventional bonds.

The initial dataset consists of 12,034 bonds out of which I identified 200 Green Corporate Bonds using the Green classification filter in Eikon. Further, the Use of proceeds classification and matching provides 554 Conventional Bond out of 11,834 , which has similar properties as green bonds. It is the final number of bonds this project is based on.

All the data prices are converted to US Dollar to ensure comparability that changes could nega- 
Table 2

Summary Statistics of the bond characteristics

\begin{tabular}{|c|c|c|c|c|c|}
\hline \multicolumn{6}{|c|}{ Green Bonds } \\
\hline \multicolumn{6}{|c|}{ Yield (bps) } \\
\hline Min. & 1st Qu. & Median & Mean & 3rd Qu. & Max. \\
\hline-0.8791 & 0.5171 & 0.9865 & 1.3298 & 1.6206 & 6.5969 \\
\hline \multicolumn{6}{|c|}{ Issue Amount (\$) } \\
\hline Min. & 1st Qu. & Median & Mean & 3rd Qu. & Max. \\
\hline $1.11 \mathrm{E}+07$ & 45700000 & 79970000 & 174300000 & 147800000 & 1071000000 \\
\hline \multicolumn{6}{|c|}{ Duration } \\
\hline Min. & 1st Qu. & Median & Mean & 3rd Qu. & Max. \\
\hline 0.2389 & 1.7124 & 3.0309 & 3.9389 & 4.4534 & 19.9647 \\
\hline \multicolumn{6}{|c|}{ Coupon } \\
\hline Min. & 1st Qu. & Median & Mean & 3rd Qu. & Max. \\
\hline 0.000 & 0.950 & 1.379 & 1.947 & 2.862 & 7.500 \\
\hline \multicolumn{6}{|c|}{ Conventional Bonds } \\
\hline \multicolumn{6}{|c|}{ Yield (bps) } \\
\hline Min. & 1st Qu. & Median & Mean & 3rd Qu. & Max \\
\hline-4.2238 & 0.7432 & 2.3571 & 3.4133 & 4.4705 & 45.2439 \\
\hline \multicolumn{6}{|c|}{ Issue Amount (\$) } \\
\hline Min. & 1st Qu. & Median & Mean & 3rd Qu. & Max \\
\hline 423500 & 110400000 & 400000000 & 491900000 & 600000000 & 8070000000 \\
\hline \multicolumn{6}{|c|}{ Duration } \\
\hline Min. & 1st Qu. & Median & Mean & 3rd Qu. & Max \\
\hline 0.1528 & 2.6331 & 4.7763 & 6.9801 & 8.7297 & 43.8285 \\
\hline \multicolumn{6}{|c|}{ Coupon } \\
\hline Min. & 1st Qu. & Median & Mean & 3rd Qu. & Max \\
\hline 0.000 & 1.500 & 3.313 & 3.599 & 4.750 & 11.500 \\
\hline
\end{tabular}

tively influence in exchange and inflation rates. As Eikon has no separate green Bond section, this paper's sample is compiled using the Green bond tag in the Eikon database. The total amount of issued green bonds between 2015-2019 is 35bn USD. The next table presents the green bond's descriptive characteristics and conventional bond.

Here, it is notable that the minimum green bond yield is negative, which possibly means the prices are so high that investors are sure to get back less than what they paid if they hold on the bond up to maturity. However, this is common in the bond market, so I have not dismissed these observations.

For testing the third hypothesis (mentioned in the upcoming chapter), I collected the carbon emission data from the GitHub website. The website conglomerate dataset from two main sources: The Global Carbon Project and the Carbon Dioxide Information Analysis Centre (CDIAC) and the World Bank. The Global Carbon Project typically update $\mathrm{CO}_{2}$ emissions annually. The dataset consists of the carbon emissions on global aggregates and carbon emissions from different industries (e.g., oil and gas, cement etc.). I matched the countries of major green bond issuance and filtered out the comparison sectors. The matching procedure is performed in Excel as it is easier to identify countries match from there. This study then checks all other indirect emissions from the sectors involved in issuing green projects. This paper intends to examine a simple benchmark 
whether a firm reduces its carbon intensity after issuing green bonds to achieve the Paris Climate goals to assess how far green bonds might contribute to the transition to a low-carbon economy. An OLS regression tests the hypothesis, and the methodology of regression are explained fully in the next chapter.

\section{Empirical Analysis}

This section contains the methodology of this thesis, which comprises the empirical research and the econometric models needed to support the hypothesis. There are two major econometric methods used in the process to study, namely, a simple multi-factor OLS regression analysis to test whether the Green Bonds are priced differently than Ordinary Bonds, and an event-study that examines the reaction on the company's stock price on the issuance of Green Bonds since it is important to know whether the issuers actually benefitted with the new instruments. In the second part, a simple OLS regression is performed to test Green Bonds' practical use of carbon emission's interaction effect when implemented jointly. Following hypotheses are established to check the main issues. As mentioned above, the first hypothesis states the purpose to find out how green bonds are priced compared to conventional ones (H1). It is then necessary to test how the issuance of green bonds affects the stock market (H2), and the third hypothesis illustrates the effectiveness of green bond tag on carbon emissions (H3).

$\mathrm{H} 1$ : There is no difference between the price of the green bond and ordinary bond.

In the literature review section, I noted that several studies showed that supranational and corporations' green bonds are priced with the premium compared to ordinary bonds and are statistically significant. However, Hachenberg and Schiereck (2018) found no lower considerable difference in the pricing of green bonds over conventional bonds in the secondary market. Therefore, this hypothesis will be tested with simple OLS regression to find a significant difference between these yields.

H2: Stock Market reacts positively on the issuance of the green bond.

According to Flammer (2020); Tang and Zhang (2018) findings, the stock market responds positively to Green Bonds' issuance. It signals the company's commitment to a green project and environment. Contrary to these findings, Lebelle et al. (2020) found market reacts negatively to green bonds' issuance. Thus, this hypothesis tests if green bonds are cheaper than ordinary ones, it should positively impact the company's stock price. It marks that the first hypothesis should be rejected.

H3: Green Bond issuance is associated with reducing carbon intensities at the firm level.

The third hypothesis tests whether a green bond tag helps build a carbon-neutral economy. Since there is limited literature on the connection between Green Bond tag and carbon emission from firms, this would be interesting to test this hypothesis. An OLS regression is performed with added controlled robustness test.

\section{Model for the Firms issuing Green Bonds}

This theoretical model explains how firms in bond and stock market choose between the green and conventional projects which explains the desired results. This model follows new literature on Green Finance (Daubanes et al., 2019), which uses the green finance firms' continuum model.

Mass- 1 continuum of projects and dates $t=0,1$.

Suppose 1 unit of capital at date $t=0$ predicts Revenue ' $\mathrm{Y}$ ' at date $t=1$. On day 0 , the choice between green $(G)$ and conventional $(B)$ project is ' $k$ '. And $\mathrm{CO}_{2}$ emissions at date $t=1: \mathrm{x}_{\mathrm{B}}>\mathrm{x}_{\mathrm{G}}>=0$. And the tax on $\mathrm{CO}_{2}$ is $w$, penalising the green firm less heavily. Firms differ by $\mathrm{CO}_{2}$ abatement cost: Firm $i \in[0,1]$ has cost $c_{B}$ if $k=B$ and $c_{G}$ if $k=G$. Project financed by bonds that repay $R=1+r$ is exogenous. At $t=1$, a profit of firm $i \in[0,1]$ with project green or conventional is

$$
\pi=\pi_{k}(i)=Y-R-C_{k}(i)-\tau x_{k} .
$$

At $t=0$, firm manager observes $i$ and choose $k=G, B$ :

$$
\max _{k} U_{k}(i)=\alpha \frac{\pi_{k}(i)}{1+\rho}+(1-\alpha) S_{k} .
$$

Where profit at $t=1$ is anticipated by a manager but not market and stock price $S_{k}$ at $t=0$ is the function of $k$. The stock investors require exogenous return $\rho$. They observe firms' project choice $k=G, B$ but particularly not projects' type $i$. The stock price at date $t=0^{+}$is 


$$
S_{k}=\frac{E\left[\pi_{k}(i) \mid k\right]}{1+\rho} .
$$

If the stock investors react positively to the green bond issuance:

$$
\Delta S=S_{G}-S_{B} \geq 0
$$

Now the volume of green bonds issued by firms is $i^{e}$. The stock market reaction in equilibrium is amplified as

$$
\Delta S\left(i^{e}\right)=\frac{\alpha}{1+\rho}\left(c_{G}\left(i^{e}\right)-\overline{c_{G}}\left(i^{e}\right)\right)>0 .
$$

And the abnormal returns at issuance follow:

$$
\mathcal{A}_{G}\left(i^{e}\right)=\left(1-i^{e}\right) \frac{\Delta S\left(i^{e}\right)}{S^{0}\left(i^{e}\right)}>0 .
$$

Where ex-ante stock price is

$$
S^{0}\left(i^{e}\right)=i^{e} S_{G}\left(i^{e}\right)+\left(1-i^{e}\right) S_{B} .
$$

\section{Econometric Methodology}

\section{Multi-Factor Regression on Bond Prices}

To investigate whether Green Bonds are priced differently, or the same as Conventional Bonds, a standard regression for Bond coupons is carried out. This part follows the same econometric strategy explained by Fatica, Panzica, and Rancan (2019), which follows the traditional crosssectional OLS regression as Fama and French (2007) used. An OLS model's advantage is that it is simple and has a large body of research that discusses suitable determinants. If correctly implemented, it could be used to draw general conclusions. Green Bond are very similar to Conventional bonds, as mentioned in the above section of this thesis, so there is no reason to believe that they differ significantly in terms of explanatory factors. The econometric model is as follows:

$$
\text { Coupon }_{b, i, t}=\beta_{0}+\beta_{1} \text { Green }_{b, i, t}+\beta_{2} X+\varepsilon_{b, i, t} \text {, }
$$

where the dependent variable Coupon refers to the coupon at the issuance of the corporate bond $b$ issued by firm $i$ in time $t_{\text {. Green }}$ G,i,t $_{\text {is a }}$ green bond dummy variable which equals one if a bond is green and zero otherwise, and it is the main variable of interest. Independent variable $X$ is a set of controlled variables that may affect the bond's coupon. The control variables are mainly the dummy variable of the other bond characteristics such as Callable, which is equal to one if a bond is redeemed prior to the maturity date, zero otherwise; puttable, which is equal to one if the bond is puttable, zero otherwise. Further, the other variable is the bond's duration, which determines the bond's maturity time, the bonds with shorter maturity return principal to Investors earlier than the long-term bond. The result of the regression is as follows:

Table 3 shows that the Green Bond Dummy variable's coefficient, which is the main variable of our interest, is negative (-2.27) and statistically significant at $1 \%$ confidence level. It suggests that the Green Bond is priced approximately 227 basis point cheaper than the conventional bonds, and that is why issuers prefer green bonds over ordinary bonds. Other controlled variables also showed statistically significant results, which can be interpreted as for example, if the company's bond has a putable feature, resulting in a higher coupon rate (2.30) based on the sample taken. In general, a putable feature is an added benefit for the bondholder. It makes able to sell the bond if the market interest rate rises and has a lower yield to compensate the issuer. Duration indicates the average time until the cash flows are received and measured in years. It is equal to the bond's maturity if the bond is a zero-coupon bond, which in this case some conventional bonds are zerocoupon bonds. The positive coefficient (0.04) indicates the significant positive relationship with the coupon which means if there is a high coupon bond, then the repayment will be faster which is in line with the theory of the relationship between coupon and the Macaulay duration of the bond. Green Bond characteristics are no less different from the ordinary bond. This comparison seems somewhat expected compared to prior studies (Fatica, Panzica, \& Rancan, 2019) but probably should not be taken as an unquestionable truth but more as an indicative result. In the regression result, R-squared seems to be relatively low, which can affect the determining result. It can be robust by adding more control variables, but the risk of variable robustness can be present. It also means that although the green bonds are 
The Multi-Factor Regression result on the sample of data from 2015 to 2019

\begin{tabular}{|c|c|c|c|}
\hline Variables & Coefficients & Std. Error & P-values \\
\hline C & 4.06132 & 0.17812 & $2 e-16^{* * *}$ \\
\hline GreenBondDummy & -2.27116 & 0.20892 & $2 e-16^{* * *}$ \\
\hline CallableDummy & -1.28636 & 0.20134 & $3.02 \mathrm{e}-10^{* * *}$ \\
\hline PutableDummy & 2.30751 & 0.67653 & $0.000684^{* * *}$ \\
\hline Mac. Duration & 0.04031 & 0.01614 & $0.012740 *$ \\
\hline Multiple R-squared & 0.1737 & & \\
\hline Adjusted R-squared & 0.169 & & \\
\hline F-statistic & 37.2 & & \\
\hline p-value & $2.2 \mathrm{e}-16$ & & \\
\hline
\end{tabular}

Notes.

The coupon is the independent variable.

All other specifications include a set of bond fixed effects.

The variable's significance level is indicated as ${ }^{*} 10$ per cent, ${ }^{* *} 5$ per cent, and ${ }^{* * *} 1$ per cent.

statistically significant, this analysis should not be considered as too definite with the resulted coefficient level.

The next table consists of the same regression with some robustness checks. It adds more control variables such as the yield spread of the comparable bonds and Sinkable dummy (1) or (0), which adds to bonds' characteristics and limit imbalances between green and conventional bonds. The sector variable is also included in the regression to control potential effects and increase the coefficient of determination.

Robustness check shows that Green Bond's main variable remains statistically significant with a coefficient $(-1.93)$, which is slightly different from the first regression result indicating the result is improving on adding a more controlled variable. Results of Callable and Putable dummy variable remained quite similar to the previous regression. However, the added controlled variable sinkable dummy does not provide a statistically significant result. Yield Spread (0.003) is showing significant coefficients. In this regression, r-squared (50 per cent) seems to be slightly higher than the previous one (32 per cent). It can be explained with the added control variables and sectors dummy, but the risk of variables robustness is still present.

In contrast to the study of Fatica et al. (2019), my study observes much lower r-squared degree; their study received an r-squared of more than 70 per cent. It may be explained by the fact that their study has a large data sample and from a more extended period, and the methodology more comprehensive. For example, their study used a fixed effect maturity $\times$ rating $\times$ time variable and controlled time-invariant unobservable firm-specific characteristics using an issuer effect. However, this paper does not reach the same level of excellence but gives similar results compared with their studies. Improvements could be made by widening the data and period of research and including financial institutions as well. The results taken from the regression used in this study should not be taken certain but more as indicative.

\section{Event Study Analysis}

This section explores what happens to a company's stock price that issues the green bonds. According to market efficiency hypothesis stock price reflects all available information and adjust rapidly to any new information (Fama et al., 1969). Hence, this study will check the market's reaction at the time of issuance of the green bond through the change in the stock price. The company chosen for the study is selected from the data sample used in this paper whose stocks are as liquid as possible. The company's stock's liquidity helps to understand the channels and mechanisms underlying positive announcement effects. The null hypothesis assumes that 
Table 4

Multi-Factor regression Result

\begin{tabular}{cccc}
\hline Variables & Coefficients & Std. Error & P-values \\
\hline C & -0.1485778 & 1.8312157 & 0.93536 \\
GreenBondDummy & -1.9274871 & 0.1946857 & $2 \mathrm{e}-16^{* * *}$ \\
CallableDummy & -1.3354209 & 0.1725375 & $3.67 \mathrm{e}-14^{* * *}$ \\
PutableDummy & 2.3016284 & 0.5554375 & $3.85 \mathrm{e}-05^{* * *}$ \\
SinkableDummy & -0.1554058 & 0.5712561 & 0.78567 \\
Mac. Duration & 0.0089604 & 0.0145913 & $2 \mathrm{e}-16^{* * *}$ \\
Yield Spread (OTR) to Maturity & 0.0031953 & 0.0002259 & \\
\hline Sector Dummy & Yes & & \\
\hline Multiple R-squared & 0.504 & & \\
Adjusted R-squared & 0.4737 & & \\
F-statistic & 16.63 & & \\
p-value & $2.2 \mathrm{e}-16$ & & \\
\hline
\end{tabular}

Notes.

Covariance method Huber-White is used for the robustness of the variables.

Statistical significance level of confidence $10 \%, 5 \%$, and $1 \%$ level is denoted by ${ }^{*},{ }^{* *},{ }^{* * *}$ respectively.

the stock prices increase after firms' green bond announcement. This event study's motivation comes from the study of Tang and Zhang (2018) and Glavas (2018), where the impact of the green bond announcement on stock price is examined through CAR analysis. This test is conducted using a 10- and 20-days window, and the market index prices are retrieved from Yahoo finance websites. Stock prices of the company are retrieved from the Datastream. This study uses the issuance date instead of the announcement day to see the market reaction as its announcement date was not clear.

\section{Abnormal returns.}

The total return prices were computed using the return index function of DataStream. The return index was based on an annualised dividend yield following Indices (2008):

$$
R I_{t}=R I_{t-1} \times \frac{P I_{t}}{P I_{t}} \times\left(1+\frac{D Y_{t} \times f}{100} \times \frac{1}{N}\right),
$$

where $R I_{t}$ is the return index on day $t, P I_{t}$ is the price index on day $t, D Y_{t}$ is the dividend yield in the percentage on day $t$ : $f$ is the grossing factor (typically 1) if the dividend yield is a net figure $f$ is used to gross up the yield. $N$ represents the number of working days in a year (usually 260) multiplied by 100 .

I used zero to five trading days windows around the bond issuance date to consider the risk of information leakage before or the under-reaction risk after the announcement of bond issuance.

The abnormal return or the firm $i$ and event day $t$ are defined as:

$$
A R_{i t}=R_{i t}-R m_{i t}
$$

$R_{i t}$ is the firm's return, and $R m_{i t}$ is the market return.

The cumulative abnormal return between $t_{1}$ and $t_{2}$ is computed as follows:

$$
\operatorname{CAR}_{i}\left(t_{1}, t_{2}\right)=\sum_{t_{1}}^{t_{2}} A R_{i t}
$$

The following table shows the CAR event study results for the mentioned time windows.

As we can see in Table 5 that there are statistically significant returns for the stock during $[-5,5]$ and $[-15,5]$ time windows. It explains that the stock market positively reacts to the green bond issuance which is in line with the study of Tang and Zhang (2018), who found abnormal re- 
turn at the same time as the company announces the issuance of a green bond. Their study found that the green bond issuer company's stock price tends to increase statistically significantly in the time frame, including the green bond issuance's announcements. The effect on the ordinary corporate issuer is stronger comparatively financial institutions. In this study, the chosen stock gives a statistically significant 0.23 per cent and 1.14 per cent cumulative abnormal return during $[-5,5]$ and $[-15,5]$ time window around the issuance of the green bond. It explains that the market reacts to the green bond price over the short time window, as both the time frame gives statistically significant results. Basically, comparing to regular bond announcements, green bond announcements blend two pieces of information i) a bond issuance, and ii) a signal of a company's commitment to the environment. Since the stock market is typically unresponsive to conventional bond issues (Flammer, 2020), the stock market's positive reaction is likely to reflect the latter. To conclude, this study indicates shareholders also benefit from the issuance of green bonds, which can be taken as an indication that issuing a green bond turns out to be beneficial for its issuer.

Nevertheless, this examination is under the risk of robustness, as it only examines one company. It is due to the lack of adequate data from companies in this thesis data. Hence, this example should not be considered for overall stock market behaviour around the green bond issuances but as supporting
Table 5

Event study outcomes through CAR analysis for the green bond issuance date

\section{Cumulative Abnormal Return (CAR)}

\begin{tabular}{ccc} 
Event Window & {$[-5,5]$} & {$[-15,5]$} \\
CAR & $0.23 \%$ & $1.14 \%$ \\
T-test & $-2.43^{* *}$ & $-2.33^{* *}$ \\
\hline
\end{tabular}

Notes.

The results are computed based on the cumulative abnormal return (CAR) comparing to the company stock and Nasdaq market index.

Data for a company's stock price over time pooled from DataStream and market index data from Yahoo finance. Testing indicates the stock price at the time of green bond issuance reacted differently or not.

Statistical significance of the variable coefficient denoted with an asterisk: ${ }^{*} 10 \%,{ }^{* *} 5 \%,{ }^{* *} 1 \%$ level of confidence.

evidence with the previous findings. This study could be more profound and comprehensive if it also includes different companies across different sectors and sizes.

\section{Environmental Performance (Green Bond and Carbon emissions)}

In this part, I examined the effectiveness of Green Bond on carbon emissions by carrying out OLS regression to understand if there is any significant relationship between how the Green Bond label market covers carbon emissions' reduction.

Table 6

The multi-factor regression result

\begin{tabular}{cccc}
\hline \multicolumn{4}{c}{ Environmental Performance } \\
\hline Variables & Coefficients & Std. Error & P-values \\
$\mathrm{CO}_{2}$ growth $(\mathrm{C})$ & 2.4302 & 0.3974 & $1.59 \mathrm{e}-09^{* *}$ \\
GreenBondLabel & -0.6198 & 0.7376 & 0.401 \\
Multiple R-squared & 0.0009921 & & \\
Adjusted R-squared & 0.000413 & & \\
F-statistic & 0.7061 & & \\
p-value & 0.401 & \\
\hline
\end{tabular}

Notes.

Carbon emissions are the dependent variable.

Green Bond label is the independent variable.

Data for carbon emission is taken from GitHub.

Green Bond Label firm wise data is presented from Thomson Reuters Eikon.

The variable's level of significance is indicated as ${ }^{*} 10 \%,{ }^{* *} 5 \%$, and ${ }^{* * *} 1 \%$. Sample data is from 2015 to 2019. 
The result shows no statistically significant relation between Green Bonds, which are classified according to the environmental rating from the same dataset used in this thesis, and the carbon $\left(\mathrm{CO}_{2}\right)$ emission growth over the years ( $\mathrm{p}$-value $>5 \%$ ). However, this result should not be considered truth, as the data collection process wasn't exact. In contrast with the methodology followed by Flammer (2020), which uses three parameters of the Green Bonds issuance; Green Bond pre-issue year which is a dummy variable equal to one in the year preceding the issuance of the green bond, and the $\mathrm{CO}_{2}$ emissions is the ratio of $\mathrm{CO}_{2}$ emissions (in tons) divided by the book value of assets. The dataset also consists of a more extensive period. Their results showed that the environmental performance goes substantially in the long run, and emissions are reduced by 13 tons of $\mathrm{CO}_{2}$ i.e., a reduction by 12.9 per cent. Compared to their studies, this result turns out to be insignificant and does not reach the same level pre-eminence.

Further, encountering the sector-wise emissions of the companies who issues the green bonds as the independent variable to check if the contributing sector has any effect on the carbon emissions, an OLS regression is carried out taking the Green Bond dummy variable and the sectors. Results are shown in Table 7.

Table 7 shows that the values are highly insignificant and have no explanatory power to illustrate that the green label decreases carbon intensity. According to Ehlers, Mojon, and Packer (BIS Quarterly Review, September 2020), "the current label of green bonds does not necessarily signal that issuers have a lower or decreasing carbon intensity". In this result, sectors that issue green bond were insignificant in relation to the carbon emission growth over those years. These findings might be abnormal due to the Carbon emission's ambiguity by any specific company. As the carbon emission data is taken from global aggregates, it is hard to explain the sectors' explicit relation and overall emissions. Taking the environment rating factor into narrower scrutiny by disaggregating the data by a company would increase the impact on the results. It can also be improved by adding the certification examination factor and indicating if the green bonds are certified or not certified within the company. It can be assumed consistent with the signalling argument that certification is costlier and reflects
Table 7

Robustness test by including Sector variable

\begin{tabular}{|c|c|c|}
\hline Variables & Coefficients & P-values \\
\hline CO2_growth (C) & 44.33 & 0.989 \\
\hline GreenBondLabelDummy & -198.62 & 0.527 \\
\hline \multicolumn{3}{|l|}{ Sectors } \\
\hline Airline & 4217.81 & 0.219 \\
\hline Automotive Manufacturer & 306.63 & 0.926 \\
\hline Beverage/Bottling & 423.19 & 0.905 \\
\hline Building Products & 678.25 & 0.835 \\
\hline Cable/Media & -25.36 & 0.994 \\
\hline Chemicals & -22.83 & 0.994 \\
\hline $\begin{array}{l}\text { Conglomerate/Diversified } \\
\text { Mfg }\end{array}$ & 1283.82 & 0.694 \\
\hline Products & 695.71 & 0.835 \\
\hline Electronics & 529.08 & 0.872 \\
\hline Processors & -13.26 & 0.997 \\
\hline Gaming & 1208.12 & 0.756 \\
\hline Gas Utility-local Distrib & 648.38 & 0.849 \\
\hline Gas Utility- Pipelines & -38.94 & 0.993 \\
\hline Health Care Facilities & 32.70 & 0.992 \\
\hline Health care Supply & -36.15 & 0.994 \\
\hline Home Builders & 1199.18 & 0.708 \\
\hline Industrials & 645.89 & 0.846 \\
\hline $\begin{array}{l}\text { Indformation/Data } \\
\text { Technology }\end{array}$ & 5035.85 & 0.128 \\
\hline Leisure & -41.49 & 0.991 \\
\hline Lodging & -43.02 & 0.991 \\
\hline Machinery & 1477.79 & 0.678 \\
\hline Metals/Mining & -33.85 & 0.992 \\
\hline Oil and Gas & 1004.76 & 0.756 \\
\hline Pharmaceuticals & 1922.18 & 0.562 \\
\hline Publishing & 397.59 & 0.914 \\
\hline Railroads & 834.73 & 0.799 \\
\hline Retail Stores-Food/Drugs & 130.75 & 0.972 \\
\hline Retail stores-Other & 528.40 & 0.876 \\
\hline Service-Other & 740.39 & 0.816 \\
\hline Telecommunications & 546.71 & 0.865 \\
\hline Textiles/Apparel/Shoes & 122.13 & 0.978 \\
\hline Tobacco & 69.18 & 0.988 \\
\hline Transportation- Other & 263.66 & 0.935 \\
\hline Utility-Other & 758.23 & 0.812 \\
\hline Vehicle Parts & 32.35 & 0.993 \\
\hline Multiple R-squared & 0.05362 & \\
\hline Adjusted R-squared & 0.003222 & \\
\hline F-statistic & 1.064 & \\
\hline P-value & 0.3705 & \\
\hline
\end{tabular}

Notes.

Carbon emission is the dependent variable and Green Bond being an independent variable.

The regression control result for each sector is introduced in the model.

The variable's level of significance is indicated as * $10 \%$, ** $5 \%$, and ${ }^{* * *} 1 \%$. 
a more robust commitment towards the natural environment (Flammer, 2019).

It is a simple benchmark. More sophisticated methods of assessing the climate-related impact of green bond issuance would require a full multivariate model to precise layout the counter fact that the change in carbon emission intensity had a firm not issuing a green bond. Overall, this analysis is merely laying out important consideration of different sector ratings to foster carbon efficiency in economic activity. Obviously, data on broader emission scopes would further help assess the overall sector's carbon footprints.

\section{Conclusions}

This paper examined the green bond market after the Paris Agreement. There are significant measures taken after that period and investigates whether the green bonds are priced lower than conventional bonds. The rapid growth in the green bond market since the genesis in 2007 and should reach $\$ 1$ trillion in the coming years. Taking four years of data from 2015 to 2019 of corporate green bonds, especially issued by non-financial companies, the main results are observed after regression testing and with some robustness check by adding more controlled variables. I thus tested three hypotheses. The first hypothesis stated that the green bond is issued with a premium compared to conventional bonds. The second tested hypothesis stated that green bonds have positive returns on stocks. The third hypothesis asserted that the green bond reduced carbon intensity at the firm level.

According to the examined sample, the result finds that the green bonds are priced cheaper than the conventional bond with 1.93 per cent premium. This finding is similar to the prior research by Fatica et al. (2019), and Baker et al. (2018) who found that bonds are priced cheaper than the conventional bond. The market has similar risk compared to the traditional market. Even though I found a slightly stronger coefficient compared to their studies, the results are in the same direction of proving the premium of green bonds. However, a wider range of robustness check is needed to get more accurate results to improve the study's quality.

The second part of this thesis investigates how the stock market responds to corporate green bonds' issuance. By carrying out an event study
(CAR-model) on different time windows $[-5,5]$ and $[-15,5]$, I get statistically significant excess returns $(0.23$ per cent and 1.14 per cent) on both time windows. The robustness test is missing from this experiment as it investigates only one company, but it shows consistent results as previous studies; Flammer (2020) who also observed the stronger response for green bonds that are certified by independent third parties and first-time issuers, and also aligns with the study of Tang and Zhang (2018).

Finally, this thesis explores the interaction effects of green bond and carbon emission. It is a very interesting part as it focuses on the efficiency of green bonds towards the practical use of these instruments, which is the vital purpose of their issuance. However, the result shows an insignificant high coefficient of change in carbon emission over the years taken in this study. Robustness check is carried out by adding the carbon emission sector-wise, and most of the sector shows an insignificant relationship with the green bonds. Overall, this part of my results is inconsistent with the line of other literature (e.g. Flammer, 2020). It can be explained because of the conciseness of the study's period. Since the high carbon emission has already become a serious concern, it can be supported by this argument that we are still far away from achieving our goal of reduction of the emissions by a remarkable amount. Prior studies use the same hypothesis but carried out different approaches to explain their results. Flammer (2020) measured environmental performance of green bonds by taking the ESG ratings of the company's and compared it with the ratio of carbon emissions divided by the book value of the assets and used a matching procedure to ensure that the treated and control firms have similar environmental performance prior to the green bond issuance. Their results found a significant positive relationship with the environment rating of a bond which goes up by seven percentage points and carbon emission reduced by 12.9 per cent indicating companies improve their environmental performance with the green bonds. Another study by Heine et al. (2019) observed this instrument to finance lowcarbon emissions by imposing carbon pricing taxes. Their study uses a three-phase model to explain how green bonds performed better when combined with carbon pricing. 
This study still calls for further research as the corporate green bonds are a new financial instrument and are relatively based on a small number of observations and criteria. However, substantially using all the previous literature finds and this thesis' results, it is somewhat clear that the green bond market has tremendous efficiency to become a financial weapon against climate change. Efforts are currently underway to enhance the green bond's performance for a better future.

\section{References}

Aaron Maltais \& Björn Nykvist. (2020). Understanding the role of green bonds in advancing sustainability. Journal of Sustainable Finance \& Investment. doi: 10.1080/20430795.2020.1724864.

Baker, Malcolm P., Bergstresser, Daniel B., Serafeim, George, Wurgler, Jeffrey A. (October 12, 2018). Financing the Response to Climate Change: The Pricing and Ownership of US Green Bonds. doi: 10.2139/ssrn.3275327.

Beder, S. (1997). Global spin: The corporate assault on environmentalism. White River Junction, Vt: Chelsea Green Publishing.

BIS Quarterly Review. (September 2020). Green Bond and Carbon Emissions: exploring the case for a rating system at a firm level). By Torsten Ehlers, Benoit Mojon, \& Frank Packer.

Blanchard, O. (2019). Public Debt: Fiscal and Welfare Costs in a Time of Low-Interest Rates. Peterson Institute of International Economics, Policy Brief 19-2.

Bloomberg. (2019). https://www.bloomberg.com/news/articles/2019-03-24/what-are-green-bonds-and-how-greenis-green-quicktake

Chandrasekaran, A. (2018). The Liquidity Risk Effects on Green Bond Yield Spreads. https://www.semanticscholar.org/paper/The-Liquidity-Risk-Effects-on-Green-Bond-Yield-Chandrasekaran/fef3ab159168e2f2484d2222386be10bc9a78a21.

Climate Bond Initiative. Available at https://www.climatebonds.net/market/explaining-green-bonds.

Climate Bonds Initiative. (2016). Case Study: DC Water Green Bond. Retrieved from https://www.climatebonds.net/ files/files/DC\%20Water\%20case\%20study\%20-\%20final\%281\%29.pdf.

Datastream Global Equity Indices. User Guide. Issue 5. Retrieved from https://docplayer.net/14213864-Datastreamglobal-equity-indices-user-guide-issue-5.html

Daubanes, Julien Xavier, \& Rochet, Jean Charles. (2019). Green finance and climate policy. Conference: Banque de France Conference on "Economic models and tools against climate change". Available at https://www.researchgate.net/publication/338037814_Green_finance_and_climate_policy

Ehlers, Torsten, \& Packer, Frank. (September 17, 2017). Green Bond Finance and Certification. BIS Quarterly Review. Retrieved from https://ssrn.com/abstract=3042378

Ehlers, Torsten, Mojon, Benoit, \& Packer, Frank. (2020, September). Green Bond and carbon emissions: exploring the case for a rating system at the firm level. BIS Quarterly Review. Retrieved from https://www.bis.org/publ/ qtrpdf/r_qt2009c.htm

Essl, S. M., Celik, S. K., Kirby, P. A., \& Proite A. (2019). Debt in Low-Income Countries: Evolution, Implications, and Remedies. World Bank Policy Research Working Paper 8794. doi: 10.1596/1813-9450-8794.

Fatica, Serena, Panzica, Roberto, \& Rancan, Michela. (2019). The pricing of green bonds: are financial institutions special? JRC Working Papers in Economics and Finance, 2019/7. Retrieved from https://publications.jrc. ec.europa.eu/repository/bitstream/JRC 116157/jrc116157_faticapanzicarancan_gbpricing_jrc_report_01.pdf. doi:10.2760/496913.

Febi, Wulandari, Schäfer, Dorothea, Stephan, Andreas, \& Sun, Chen. (2018). The impact of liquidity risk on the yield spread of green bonds. Finance Research Letters, 27(C), 53-59.

Financial Times. (2019). Tackling climate change - an investor's guide. https://www.ft.com/content/fa7a4400d940-11e9-8f9b-77216ebe1f17

Financial Times. (2014). Unilever issues $£ 250 \mathrm{~m}$ green bond. https://www.ft.com/content/b3ea447a-af59-11e39cd1-00144feab7de

Flammer, Caroline. (April 14, 2020). Corporate Green Bonds. Journal of Financial Economics (JFE), Forthcoming. Retrieved from https://ssrn.com/abstract=3125518. doi: 10.2139/ssrn.3125518.

Forni, L., Catalano, M., \& Pezzolla, E. (2019), Increasing Resilience: Fiscal Policy for Climate Adaptation. In Pigato, M. (ed.), Fiscal Policies for Development and Climate Action (Chapter 3). Washington, DC: World Bank Group. 
Ge, Wenxia, \& Liu, Mingzhi. (2015). Corporate Social Responsibility and the Cost of Corporate Bonds. Journal of Accounting and Public Policy, 34. Retrieved from https://ssrn.com/abstract=1985218. doi: 10.2139/ssrn.1985218.

Gevorkyan, A., Flaherty, M., Radpour, S., \& Semmler W. (2017). Financing Low Carbon Transitions Through Carbon Pricing and Green Bonds - Theory and Empirics. Manuscript. New School for Social Research.

Gianfrate, G., \& Peri, M. (2019). The green advantage: Exploring the convenience of issuing green bonds. Journal of cleaner production, 219, 127-135.

Hachenberg, B., \& Schiereck, D. (2018). Are green bonds priced differently from conventional bonds? Journal of Asset Management, 19, 371-383 (2018). doi: 10.1057/s41260-018-0088-5.

Heine, Dirk, Semmler, Willi, Mazzucato, Mariana, Braga, Joao Paulo, Gevorkyan, Arkady, Hayde, Erin Kate, \& Radpour, Siavash. (2019). Financing Low-Carbon Transitions Through Carbon Pricing and Green Bonds. World Bank Policy Research Working Paper No. 8991.

Kapraun, Julia, \& Scheins, Christopher. (2019, March 5). (In)-Credibly Green: Which Bonds Trade at a Green Bond Premium? Proceedings of Paris December 2019 Finance Meeting EUROFIDAI - ESSEC. doi: 10.2139/ ssrn.3347337.

Karpf, Andreas, \& Mandel, Antoine. (2018). The changing value of the 'green' label on the US municipal bond market. Nature Climate Change, 8, 161-165. doi: 10.1038/s41558-017-0062-0.

Klassen, Robert D., \& McLaughlin, Curtis P. (1996), The Impact of Environmental Management on Firm Performance. Management Science, 42, 8, 1199-1214. doi: 10.1287/mnsc.42.8.1199.

Krüger, Philipp. (2015). Corporate goodness and shareholder wealth. Journal of Financial Economics, 115, 2, 304-329. doi: 10.1016/j.jfineco.2014.09.008.

Larcker, D. F., \& Watts, E. M. (2020). Where's the Greenium? Journal of Accounting and Economics, 69, 2-3. doi: 10.1016/j.jacceco.2020.101312.

Laufer, W.S. (2003). Social Accountability and Corporate Greenwashing. Journal of Business Ethics, 43, 253-261. doi: 10.1023/A:1022962719299.

Lebelle, M., Jarjir, Lajili S., \& Sassi, S. (2020). Corporate Green Bond Issuances: An International Evidence. Journal of Risk Financial Management, 13(2), 25. doi: 10.3390/jrfm13020025.

Maltais, Aaron, \& Nykvist, Björn. (2020). Understanding the role of green bonds in advancing sustainability. Journal of Sustainable Finance \& Investment. 1-20. doi: 10.1080/20430795.2020.1724864.

Mazzucato, M. (2015). The Green Entrepreneurial State. In Scoones, I., Leach, M., \& Newell, P. (Eds.), The Politics of Green Transitions. Abingdon: Routledge.

Mazzucato, M. (2016). From market fixing to market-creating: a new framework for innovation policy. Industry and Innovation, 23, 140-156. doi: 10.1080/13662716.2016.1146124.

Norberg-Bohm, V. (2000). Creating Incentives for Environmentally Enhancing Technological Change: Lessons From 30 Years of US Energy Technology Policy. Technological Forecasting and Social Change, 65(2), 125-148. Retrieved from https://user.iiasa.ac.at/ gruebler/Lectures/skku_2009/readings/norberg-bohm_tech_incentives_2000.pdf

Queen, Irene. (2016). Green Bonds \& Climate Change. Retrieved from https://www.researchgate.net/publication/314244123_Green_Bonds_Climate_Change

Sartzetakis, E.S. (2020). Green bonds as an instrument to finance low carbon transition. Economic Change and Restructuring. doi: 10.1007/s10644-020-09266-9

Shishlov, Igor, Morel, Romain, \& Cochran, Ian. (2016). Beyond transparency: unlocking the full potential of green bonds. I4CE - Institute for Climate Economics. doi: 10.13140/RG.2.2.11081.85606

Tang, Dragon Yongjun, \& Zhang, Yupu. (2018, October 25). Do Shareholders Benefit from Green Bonds? doi: 10.2139/ ssrn. 3259555

Wadhwa, Saloni R. (2020). Are Green Bonds Just Another Financial Fad or Are They Here to Stay? Wharton Research Scholars. 193.

Zerbib, Olivier David. (2016, December 25). Is There a Green Bond Premium? The Yield Differential Between Green and Conventional Bonds. Published also as Zerbib, Olivier David. (2019). The effect of pro-environmental preferences on bond prices: Evidence from green bonds. Journal of Banking and Finance, 98, 39-60. doi: 10.2139/ssrn.2889690 


\section{Websites References}

https://www.bis.org/publ/qtrpdf/r_qt2009c.htm

https://github.com/owid/co2-data

https://www.bbva.com/en/bbva-green-bonds-reduced-the-carbon-footprint-by-724-tons-of-co2-in-2019/

https://corporatefinanceinstitute.com/resources/knowledge/other/greenwashing/

https://www.noaa.gov/news/noaa-2017-was-3rd-warmest-year-on-record-for-globe

https://www.climatebonds.net/files/reports/cbi_gbm_final_032019_web.pdf

https://fortune.com/2017/06/13/apple-second-green-bond/

Практическая жизнеспособность зеленых облигаций и экономические выгоды

\section{Аникита Кант}

Аннотация. Зеленые, или «климатические», облигации часто рассматриваются в качестве финансового инструмента, который способен преодолеть отказ от зеленых инвестиций. В статье представлены результаты исследования потенциального вклада и роли зеленых облигаций, связанных с переходом к низкоуглеродным технологиям, а также выгоды корпоративного сектора. Рынок зеленых облигаций находится под постоянным контролем с момента их появления в 2007 г. С течением времени значение их воздействия в борьбе с изменением климата постоянно растет, что можно рассматривать как аргумент в пользу инвестирования в зеленые облигации. Используя критерии соответствия и выполнив многомерную регрессию OLS, автор задался целью проверить, отличается ли цена зеленой облигации от цены обычных. Результат показывает, что зеленые облигации дешевле обычных с премией 1,93-2,24\%, что согласуется с предыдущими исследованиями по этой теме. Используя выборку из 200 корпоративных зеленых облигаций, выпущенных после Парижского соглашения (с декабря 2015 по декабрь 2019 г.), автор с помощью теста CAR документально подтвердил, что фондовый рынок положительно реагирует на объявления о зеленых облигациях. Полученные в ходе исследования результаты предполагают, что, возможно, зеленые облигации работают хорошо с экономической точки зрения, но все еще далеки от достижения своей практической цели. Ключевые слова: зеленые облигации; изменение климата; выбросы углекислого газа; налог на выбросы парниковых газов; корпоративные финансы 